\title{
Interactions between GH, IGF-I, Glucocorticoids, and Thyroid Hormones during Skeletal Growth
}

\author{
HELEN ROBSON, THOMAS SIEBLER, STEPHEN M. SHALET, AND GRAHAM R. WILLIAMS \\ Department of Clinical Research [H.R.], Department of Endocrinology [S.M.S.], Christie Hospital \\ National Health Service Trust, Manchester, U.K.; University Children's Hospital, University of Leipzig, \\ Leipzig, Germany [T.S.]; IC Molecular Endocrinology Group, Division of Medicine and MRC Clinical \\ Sciences Centre, Faculty of Medicine, Imperial College School of Science Technology and Medicine, \\ Hammersmith Hospital, London, U.K. [G.R.W.]
}

\begin{abstract}
ABST
Linear growth occurs during development and the childhood
years until epiphyseal fusion occurs. This process results from
endochondral ossification in the growth plates of long bones and
is regulated by systemic hormones and paracrine or autocrine
factors. The major regulators of developmental and childhood
growth are GH, IGF-I, glucocorticoids, and thyroid hormone.
Sex steroids are responsible for the pubertal growth spurt and
epiphyseal fusion. This review will consider interactions between
GH, IGF-I, glucocorticoids, and thyroid hormone during linear
growth. It is well known from physiologic and clinical studies
that these hormones interact at the level of the hypothalamus and
pituitary. Interacting effects on peripheral tissues such as liver are
also well understood, but we concentrate here on the epiphyseal
growth plate as an important and newly appreciated target organ
for convergent hormone action. (Pediatr Res 52: 137-147, 2002)
\end{abstract}
\section{PREPUBERTAL GROWTH}

GH and IGF-I. Disruption of the GH/IGF-I axis causes an IGF-I deficiency syndrome that is characterized by growth retardation due to failure of $\mathrm{GH}$ production or $\mathrm{GH}$ resistance. Failed production results from genetic abnormalities (1-4),

Received July 16, 2001; accepted April 3, 2002.

Correspondence and reprint requests: G.R. Williams, Imperial College Molecular Endocrinology Group, 5th Floor, Medical Research Council Clinical Sciences Centre, Hammersmith Hospital, Du Cane Road, London W12 0NN, U.K.; e-mail: graham.williams@ic.ac.uk

Supported by MRC Career Establishment Grant (G9803002) and Wellcome Trust Project Grant (50570) to G.R.W. T.S. was supported, in part, by a European Society for Paediatric Endocrinology Research Fellowship, sponsored by Novo Nordisk A/S.

DOI: 10.1023/01.PDR.0000023494.70201.1C

\section{Abbreviations}

5'-DI, 5'-iodothyronine deiodinase

FGF, fibroblast growth factor

FGFR, fibroblast growth factor receptor

GC, glucocorticoid

GHR, GH receptor

GR, glucocorticoid receptor

HSPG, heparan sulfate proteoglycan

11 $\beta$ HSD, $11 \beta$-hydroxysteroid dehydrogenase

IGF-IR, IGF-I receptor

IGFBP, IGF binding protein

Ihh, Indian hedgehog

JAK-2, Janus-activated kinase-2

PTHrP, PTH-related peptide

RTH, resistance to thyroid hormone

STAT, signal transducers and activators of transcription

T3, 3,5,3'-L-triiodothyronine, thyroid hormone

T4, L-thyroxine TR, thyroid hormone receptor hypothalamic or pituitary malformations (5), trauma, inflammation, tumors (6), radiation (7), psychosocial disorders (8), and neurosecretory abnormalities (9). GH resistance results from GHR mutations (10), postreceptor signaling defects, and defects of IGF-I synthesis, or may be secondary to chronic disease, malnutrition (11), or circulating GH or GHR antibodies. Defects in genes encoding GH (2), the Pit-1 transcription factor (1), and GH releasing hormone receptor (4) cause severe $\mathrm{GH}$ deficiency, but the associated growth retardation results from predominant postnatal growth failure. Similarly, mild growth retardation is apparent at birth in $\mathrm{GH}$ insensitivity and other causes of congenital GH deficiency. In contrast, intrauterine growth retardation was severe in the single reported case of IGF-I gene deletion (12), suggesting that IGF-I exerts 
major influences during fetal growth. In neonates, growth failure due to GH deficiency is established by 6 mo and may result in short stature 3 or 4 SD below the mean.

Glucocorticoids. Excess glucocorticoids enhance bone resorption, inhibit osteoblast activity, and reduce bone matrix production to cause growth retardation in children $(13,14)$ and osteoporosis in adults (15). These effects are related to duration of GC excess and occur irrespective of its etiology. Long-term $\mathrm{GC}$ excess also interferes with GH pulsatility and decreases total GH secretion by elevating hypothalamic somatostatin tone (16). Nevertheless, growth impairment due to excess GC is associated with normal circulating GH and IGF-I concentrations, suggesting there is peripheral insensitivity to both hormones, an interpretation supported by the requirement for pharmacological doses of $\mathrm{GH}$, which only partially overcome growth retardation in GC excess (17). Furthermore, GC inhibit calcium absorption and reabsorption in the gastrointestinal tract (18) and kidney (19), and may cause secondary hyperparathyroidism. They induce sex hormone deficiency and alter vitamin D metabolism, leading to deleterious effects on growth and skeletal integrity (20). Growth retardation resulting from excess GC is dose-related, may be severe, and is difficult to treat. Exposure to excess hormone should be corrected early or GC treatment can be limited by intermittent dosing, although this may not prevent bone loss (21). Treatment with GH in the presence of continuing GC therapy or after correction of GC excess often fails to achieve target height, suggesting that deleterious effects of $\mathrm{GC}$ on the growth plate are persistent and resolve only partially after steroid withdrawal (22).

Thyroid hormones. Childhood hypothyroidism causes growth failure, but other features of adult hypothyroidism are often absent. Growth failure may develop insidiously, but is severe once established. In untreated hypothyroidism, complete growth arrest occurs with delayed bone age, epiphyseal dysgenesis, and immature body proportion (22). A proportion of patients with T3 resistance, caused by mutant T3 receptor $\beta$ proteins, suffer from growth retardation and developmental abnormalities of bone (23) that reflect tissue hypothyroidism. T4 replacement induces rapid catch-up growth, although this may be incomplete because bone age advances faster than the increase in height (24). The deficit in final height after treatment correlates with the duration of hypothyroidism. Catch-up growth may be especially compromised if treatment is required at or around the onset of puberty, when it may be appropriate to treat with lower T4 replacement doses and add therapy to delay puberty and epiphyseal fusion. In accord with this, childhood thyrotoxicosis causes accelerated growth and advanced bone age, which may lead to craniosynostosis, premature growth plate closure, and short stature $(24,25)$.

\section{GROWTH PLATE STRUCTURE}

The epiphyses and metaphyses of long bones originate from independent ossification centers and are separated by a growth plate (Fig. 1A). The growth plate becomes ossified after puberty and epiphyseal fusion occurs. In the normal growth plate, immature cells lie toward the epiphysis, with mature chondrocytes adjacent to the primary spongiosum, which lies in continuity with the bone marrow. The reserve zone contains small clusters of progenitor cells within a matrix of type II collagen and proteoglycans. Flattened chondroblasts undergo clonal expansion in the proliferative zone and form organized columns. Proliferative chondrocytes secrete matrix and enlarge as they mature. The largest proliferative cells differentiate to form hypertrophic chondrocytes, which secrete type $\mathrm{X}$ collagen. Hypertrophic chondrocytes enlarge by five times their volume and eventually undergo apoptosis to leave lacunae separated by cartilaginous septae that become calcified and form a scaffold for new bone formation (Fig. 1B). New blood vessels enter from the primary spongiosum and osteoblasts invade from the bone marrow to lay down trabecular bone and complete the endochondral ossification process. These processes have been reviewed in detail $(26,27)$.

Recent experiments have established that chondrocyte differentiation during bone development and growth is regulated by a negative feedback loop involving the paracrine factor Ihh $(28,29)$ and PTHrP $(30,31)$. Ihh is secreted by prehypertrophic chondrocytes and stimulates production of PTHrP from the periarticular region of the epiphysis (28-32). PTHrP acts on PTHrP-receptor expressing prehypertrophic chondrocytes to maintain cell proliferation, reduce Ihh production, and complete a feedback loop in which PTHrP exerts a negative signal that inhibits hypertrophic differentiation (Fig. 2). The physiologic importance of other autocrine, paracrine, or systemic factors to influence bone formation via this pathway must also now be considered with the demonstration that retinoic acid stimulates Ihh expression in primary cultured growth plate chondrocytes (33), our finding that expression of growth plate PTHrP and PTHrP receptor mRNA is sensitive to thyroid status in vivo (34), and evidence that bone morphogenetic proteins influence expression of its signaling components $(35,36)$. The importance of this feedback loop has also been demonstrated in man by the rare inherited conditions Jansen's metaphyseal and Blomstrand chondrodysplasias, which are characterized by delayed or advanced endochondral ossification, respectively. Jansen's metaphyseal dysplasia results from constitutively active PTHrP-receptors (37), whereas, in Blomstrand chondrodysplasia, the mutated receptor is nonfunctional (38), thus confirming the requirement for correct PTHrP signaling in the programming of human endochondral ossification.

\section{HORMONE ACTION IN SKELETAL CELLS}

GH and IGF-I. The growth-promoting actions of GH and IGF-I have been reviewed recently (39). The original somatomedin hypothesis (40) proposed that GH stimulates hepatic production of IGF-I, which in turn promotes growth directly at the epiphyseal plate. Subsequently, the dual somatomedin hypothesis (41) proposed that local IGF-I promotes chondrocyte maturation and longitudinal growth in an autocrine/paracrine fashion (42), while hepatic IGF-I exerts feedback control on pituitary GH secretion (43). However, this does not account for the additional direct actions of GH on bone. Thus, GH induces unilateral epiphyseal growth when injected (44) or infused locally (45) and promotes chondrocyte proliferation in vitro (46). Furthermore, IGF-I neutralizing antibodies block the proliferative effects of GH (17), to suggest an additional local 

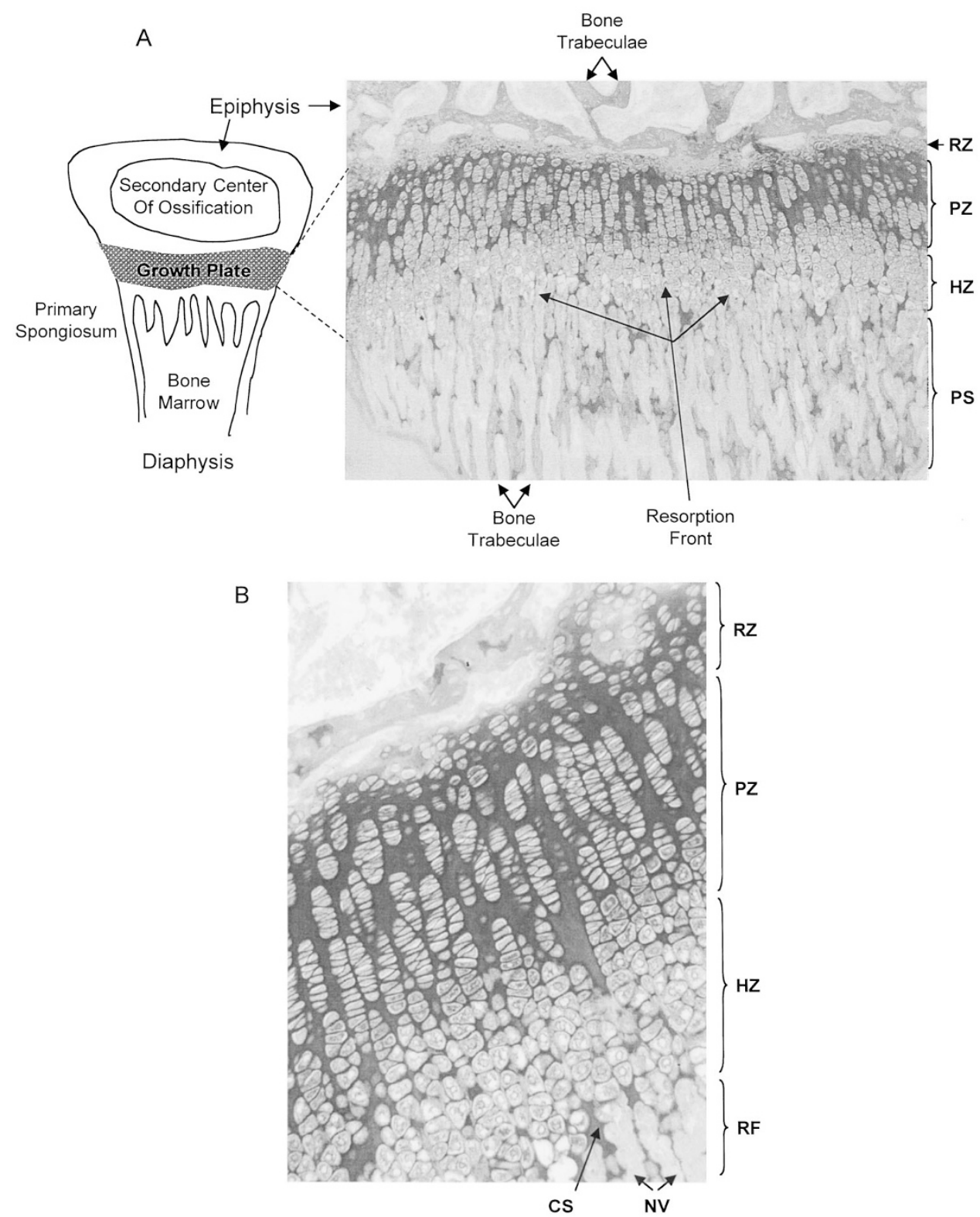

Figure 1. Structure of the growth plate. $(A)$ Diagram of the growth plate in relation to the upper end of a long bone alongside a section of normal growth plate from a 3-wk-old mouse stained with Alcian blue/van Gieson. $R Z$ indicates reserve zone; $P Z$, proliferative zone; $H Z$, hypertrophic zone; $P S$, primary spongiosum. The resorption front is the region where cartilage is ossified by invading osteoblasts. $(B)$ High-power view of the growth plate. $R F$ indicates resorption front. Small, rounded progenitor cells are present in the RZ, columns of flattened proliferating chondrocytes in the RZ, and enlarging hypertrophic cells in the HZ. Cartilaginous septae $(C S)$ are seen in the RF, where osteoblasts invade via new vessels $(N V)$ that invade from the underlying bone marrow.

somatomedin hypothesis, in which GH actions in chondrocytes are mediated by local IGF-I production (Fig. 3).

Infusion of GH or IGF-I shortens stem and proliferating cell cycle times in the growth plate of hypophysectomized rats and decreases the duration of the hypertrophic differentiation phase, with GH being more effective. GH or IGF-I treatment restores mean cell volume and height, but the growth rate is not normalized by either hormone (47). The rats in this study were hypothyroid, and treatment with infused GH or IGF-I for $8 \mathrm{~d}$ did not alter thyroid status. Furthermore, the GC axis was not investigated, and it is likely, therefore, that incomplete recovery after GH or IGF-I replacement resulted from uncorrected hypothyroidism and altered GC signaling. Nevertheless, it was concluded that both IGF-I and GH stimulate growth plate chondrocytes at all stages of differentiation, and that $\mathrm{GH}$ actions are mediated predominantly via IGF-I but also by direct IGF-I independent effects (47). This has since been described as the "dual effector theory" (41), in which GH acts selectively on stem cells but also promotes chondrocyte proliferation via local IGF-I production. IGF-I is proposed then to stimulate clonal expansion of proliferating cells in an autocrine/paracrine manner (48).

GHR and IGF-IR are expressed at all stages of growth plate chondrocyte differentiation in many species $(47,49-54)$ (Fig. 2). Distribution of the GHR varies with age. It is only present in hypertrophic chondrocytes in neonatal rabbits, but becomes more widespread at 20-50 d and appears in reserve zone and proliferative cells. In 3- to 8-mo-old humans, GHR protein is 
A

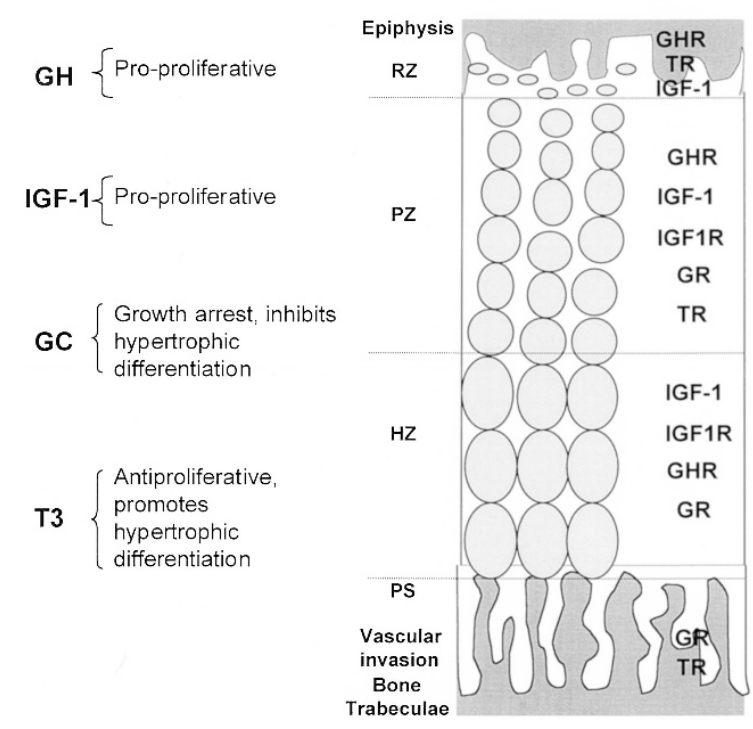

C

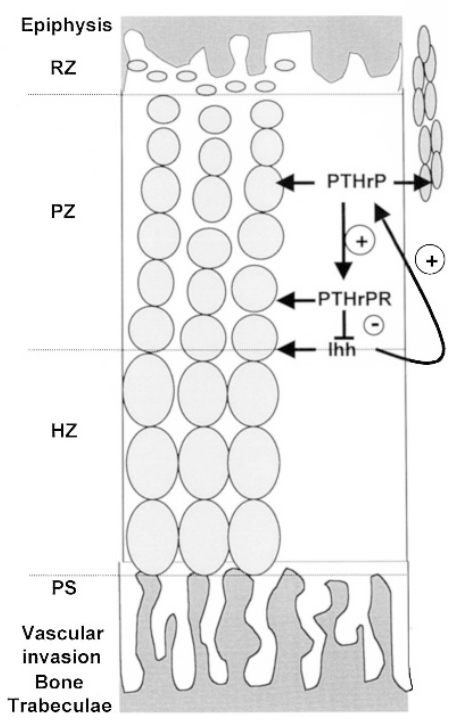

Figure 2. Hormone action in the growth plate. $A$ indicates the effects of GH, IGF-I, GC, and T3 on growth plate chondrocytes. $B$ demonstrates regions of the growth plate in which IGF-I and GHR, IGF-IR, GR, and TR are expressed. $R Z$ indicates reserve zone; $P Z$, proliferative zone; $H Z$, hypertrophic zone; $P S$, primary spongiosum. $C$ shows the Ihh/PTHrP feedback loop, which regulates the pace of endochondral ossification. Ihh is secreted by prehypertrophic chondrocytes and acts on perichondrial cells during development, or on proliferative chondrocytes during postnatal growth, to stimulate release of PTHrP. PTHrP acts on PTHrP receptors $(P T H r P R)$ that are expressed in uncommitted prehypertrophic chondrocytes to delay differentiation and maintain cell proliferation.

expressed in proliferative and hypertrophic chondrocytes and immunostaining has been documented in fetal growth plates of 12-16 wk gestation.

GH binding to its receptor causes recruitment and activation of the receptor-associated JAK-2, which in turn activates members of the family of STAT (55). In particular, the growth retardation described in STAT5 $a b^{-1-}$ mice suggests that STAT5 proteins largely mediate GH effects on bone growth (56), although a more recent study of GHR null mice suggested that bone homeostasis in these animals could be restored by IGF-I via a pathway that was independent of STAT5 (57). Importantly, FGF, which also play a major role in both endochondral and intramembranous ossification (58-60), have been shown to activate the STAT1 signaling pathway and mediate the inhibitory effects of FGF on chondrocyte proliferation that are mediated mainly by FGFR3 $(61,62)$. These results indicate an essential role for STAT signaling pathways in the control of chondrocyte proliferation during endochondral bone formation in the growth plate and suggest a point of convergence for interaction between GH and FGF signaling during growth.

IGF and IGFBP are also expressed in growth plate chondrocytes. In fetal bovine growth plates, IGF-I and IGF-II expression occurs mainly in proliferating chondrocytes, although others have identified IGF-I mRNA in hypertrophic and proliferating chondrocytes or in all zones of the postnatal rat growth plate $(47,63)$. IGF-I has important direct effects on proteoglycan synthesis and cell proliferation, however, these actions are modulated by noncovalent associations between IGF-I and IGFBP that limit the bioavailability of IGF-I. Furthermore, a range of factors, including IGF-I, IGF-II, insulin, and transforming growth factor $\beta 1$, differentially modulate the expression and release of IGFBP from cultured fetal tibial growth plate chondrocytes, suggesting a role in the control of local IGF action (64). Surprisingly, other factors that are involved in the regulation of chondrogenesis, including $\mathrm{GH}$, FGF2, and T4, had no effect on IGFBP expression and release in these experiments. High concentrations of IGFBP have also been associated with inhibition of IGF activity and impairment of longitudinal growth in children with chronic renal failure, although a recent study demonstrated differential effects of IGFBP to either stimulate or inhibit IGF-I-induced chondrocyte proliferation, depending on whether they were present as intact molecules or proteolysed fragments (65). This is further complicated by a recent report concerning mesenchymal chondrogenic RCJ3.1C5.18 cells, in which the antiproliferative effects of IGFBP3 were influenced by the stage of chondrocyte differentiation (66). IGFBP-3, -4 , and -5 are expressed in proliferating cells and hypertrophic chondrocytes, whereas IGFBP-2 expression occurs throughout the growth plate (50), and IGFBP-1 inhibits the growth-promoting effects of IGF-I and $\mathrm{GH}$ in the growth plate in hypophysectomized rats (67). Taken together, these studies indicate that IGF-I action in bone is subject to complex and subtle regulation of its bioavailability by locally expressed IGFBP that are secreted in varying combinations and concentrations.

The activity of IGFBP has been shown further to be differentially regulated by GC (68), an observation that may be relevant to the growth-inhibiting effects of GC. Thus, dexamethasone inhibited IGFBP-5 expression, a potentiator of IGF-I action in chondrocytes $(69,70)$, but up-regulated IGFBP-3 mRNA and protein, which has been reported by some (71), but not others (72), to have an inhibitory effect on IGF-I action. Despite the in vivo and in vitro studies that have addressed the regulation of IGFBP by GC, the results have varied considerably between IGFBP, the types of cells studied, and the experimental conditions. Another level of interaction 
that deserves consideration in this context is the effect of IGF-I on matrix proteoglycan synthesis. As indicated above, this may modulate IGFBP availability in the growth plate. Additionally, structural modifications to HSPG within the growth plate are likely to impact on FGF/FGFR signaling because binding of FGF to its receptor requires heparan sulfate $(73,74)$ and altered expression and structure of HSPG modulates FGFR signaling in a ligand- and receptor-specific fashion $(75,76)$. Furthermore, matrix HSPG act as a reservoir for delivery of FGF, indicating that modulation of matrix proteoglycan secretion and structure is likely to play an important role in dictating growth plate chondrocyte responses to both the IGF/IGFBP and the FGF/FGFR signaling pathways. Regulation of chondrocyte matrix secretion and proteoglycan structure by systemic hormones such as glucocorticoids $(77,78)$ and T3 (34) adds further complexity to the convergence of systemic hormones and local autocrine/paracrine factors at the growth plate.

Glucocorticoids. Evidence for a direct effect of GC in the growth plate came from a study in which local dexamethasone infusion markedly decreased tibial growth compared with the contralateral limb (79). The GR has since been identified in proliferating and hypertrophic chondrocytes and in osteoblasts and osteocytes in the rat (80). GR is also expressed in human growth plates, mainly in hypertrophic chondrocytes and in osteoblasts at sites of bone remodeling, but is not expressed in osteoclasts, suggesting that effects of GC on bone resorption are indirect (81). GC inhibit osteoblast proliferation, enhance their differentiation, and enhance bone resorption, probably via increases in collagenase expression with concomitant reduced expression of tissue inhibitors of matrix metalloproteinase (82, 83). GC also inhibit type I collagen gene expression so that there is a simultaneous decrease in bone matrix production with increased levels of proteases that degrade it. Furthermore, excess GC induce apoptosis of osteoblasts and osteocytes in rabbit trabecular bone (84), and in osteoblasts in rat long bones (85), resulting in an almost complete absence of new bone formation. In rats, GC excess also reduces growth plate width, possibly due to decreased numbers of proliferative chondrocytes and increased apoptosis in terminal hypertrophic chondrocytes (86). These results are also consistent with the dexamethasone-induced inhibition of chondrocyte proliferation and cartilage matrix production observed in 3-mo-old rats in vivo (87), suggesting that dexamethasone is a potent negative regulator of the progression of chondrogenesis. It is likely, however, that dexamethasone also acts as a stimulator of chondroprogenitor cell recruitment and supporter of chondrocyte viability $(88,89)$. Dexamethasone enhances expression of the Sox-9 transcription factor (90), which regulates expression of genes encoding markers of commitment to chondrogenesis, including Col2al and aggrecan, to further support the notion that dexamethasone is a maintenance factor for chondrogenic cells. This effect on Sox-9 mRNA and protein expression was observed within $24 \mathrm{~h}$. Indeed, Murakami et al. (91) also reported that FGF-2 increased Sox-9 mRNA expression in primary cultures of chondrocytes as early as $30 \mathrm{~min}$ after its addition, an effect that lasted at least up to $24 \mathrm{~h}$. FGF signaling in chondrocytes also results in an inhibition of proliferation (62) and thus it is possible that the effects of dexamethasone on
Sox-9 are indirect and involve FGF signaling $(91,92)$. In addition, Sox-9 is a target of PTHrP signaling in prehypertrophic growth plate chondrocytes, suggesting a complex interplay between these factors to influence discrete early steps during chondrogenesis $(92,93)$.

It is well established, however, that the effects of $\mathrm{GC}$ are transient and that, after their removal, there is a period of accelerated catch-up growth. It has been proposed that the mechanism governing catch-up growth after treatment of GC excess resides in the growth plate itself (94). This proposal was based on the observation that suppression of growth within a single rabbit growth plate in vivo by local administration of dexamethasone was followed by catch-up growth restricted to the affected limb. According to this model, growth inhibiting conditions of excess GC reduce the growth and maturation of growth plate stem cells, or chondroprogenitors, and conserve their proliferative potential (95). Our unpublished observation that the GR is expressed in germinal and proliferative zone chondrocytes of the rat tibial growth plate is consistent with this proposal and suggests that chondrocyte progenitors and proliferating cells are GC target cells in the growth plate. These hypotheses are further supported by our findings that dexamethasone-treated chondrogenic ATDC5 cells retain the capacity to re-enter chondrogenesis following withdrawal of GC. Thus, although dexamethasone arrests growth and differentiation of chondrocytes, the capacity for cells to undergo chondrogenesis is maintained in the presence of GC, even though progenitor cells are quiescent; the program is reactivated when dexamethasone is removed. Nevertheless, it is the additional action of dexamethasone on cells of the proliferative zone to decrease clonal expansion that, if prolonged, may contribute to the permanent height deficit observed in children treated for prolonged periods with GC (96).

The growth-suppressing effects of GC appear multifactorial, and some $\mathrm{GC}$ actions in bone may modify skeletal responses to GH and IGF-I. GC reduce IGF-I mRNA in growth plate chondrocytes (97) and inhibit basal and IGF-I-induced DNA synthesis (98). Some skeletal effects of GC may actually be mediated via decreased IGF-I expression, as evidenced by reduced expression of IGF-I, GHR, and IGF-IR in GC-treated chondrocytes $(17,99)$. In cultured osteoblasts, GC inhibit expression of IGF-I and IGFBP-1, -3, -4, and -5 (83). Thus, GC cause a generalized reduction in skeletal IGF-I expression in osteoblasts and chondrocytes. This correlates with observations that IGF-I and GC exert opposing actions in bone; IGF-I is mitogenic and GC inhibit proliferation. IGF-I also increases collagen synthesis and decreases collagenase 3 expression, whereas GC decrease and increase these parameters, respectively. It has also been reported that IGF-II overexpression in transgenic mice partially protects bone from the osteopenic effects of GC (100). Furthermore, GC prevent the induction of GHR and IGF-IR expression by GH and IGF-I in chondrocytes (17), although it has been shown previously that GC per se increase GH receptor mRNA expression in liver, growth plate, and osteoblasts $(83,101)$. Although variable effects of GC on GHR are evident between studies, the effects of GC on GHR and IGF-IR may account for peripheral GH insensitivity in patients with GC excess. Reduced numbers of peripheral GHR 
and IGF-IR may also explain antagonism of the growthpromoting actions of GH by GC, although children with impaired growth due to GC excess may still respond to pharmacological doses of GH therapy. Importantly, and in contrast to chondrocytes, GC stimulate GHR in osteoblasts (102), suggesting that insensitivity to $\mathrm{GH}$ in conditions of GC excess is mainly applicable to the detrimental effects of $\mathrm{GC}$ on growth rather than bone mass.

Of additional interest is the observation that GH, via IGF-I, inhibits activity of $11 \beta \mathrm{HSD} 1$ in human adipose stromal cells (103). $11 \beta \mathrm{HSD} 1$ is principally a reductase in vivo that converts inactive cortisone to cortisol, mainly in liver and adipose tissue, to maintain circulating levels of GC. The type 2 enzyme, $11 \beta \mathrm{HSD} 2$, is a dehydrogenase that catalyzes inactivation of GC to protect the nonselective mineralocorticoid receptor from GC activation in target tissues such as the kidney, or to prevent the passage of maternal GC across the placenta and protect the fetus (104). Thus, local tissue GC concentrations are modulated by the $11 \beta$ HSD 2 enzyme, and $11 \beta$ HSD 2 activity has been demonstrated in osteoclasts and osteoblasts (105, 106), although its function in bone is unknown (107). If $11 \beta \mathrm{HSD}$ enzymes are expressed in growth plate chondrocytes, they may act as significant GH- and IGF-I-sensitive regulators of local GC concentrations in the growth plate.

Thyroid hormones. The hypothesis that GH mediates T3 effects on growth was tested in thyroparathyroidectomized rats treated with GH, T4, or both (108). T4 reversed all the effects of hypothyroidism, which reduced growth plate width, articular cartilage, and trabecular bone volume. GH had no effect on the growth plate or metaphysis but partially restored epiphyseal trabecular bone. GH and T4 in combination increased growth plate width and metaphyseal trabecular bone above the value of T4-treated animals. Hypertrophic features of chondrocytes were absent in hypothyroid rats and were only restored by treatment with T4 or T4 plus GH, but not GH. Thus, three sites of $\mathrm{T} 3$ action were identified in which GH exerted no influence. GH did not affect stimulation of resting zone cells to differentiate. GH accomplishes this in the intact animal, but these studies indicate the action requires T3 (108). Secondly, T3 is indispensable for chondrocyte hypertrophy; and, thirdly, T3 is required for vascular invasion of the growth plate and metaphyseal trabecular bone formation (108). In contrast, reduced epiphyseal trabecular bone volume in hypothyroidism may result partly from associated GH deficiency. A similar study in mandibular condyle cartilage came to the same conclusion that abnormal bone formation in hypothyroidism can be restored by T4 but not GH (109). Immunohistochemical analysis demonstrated expression of GHR throughout the mandibular condyle, regardless of thyroid status. IGF-I was also expressed throughout the condyle, but in hypothyroidism and GH-treated rats, it was absent from reserve and proliferating chondrocytes and present only in some hypertrophic cells. These data were interpreted to indicate that chondrocyte IGF-I is downregulated in hypothyroidism and that hypothyroid cartilage is compromised in its GH responsiveness by a lack of IGF-I (109).

Although the effects of T3 and IGF-I on growth plate chondrocytes can be separated, T3 influences expression of several components of IGF-I signaling in bone. T3 increases IGF-I mRNA in osteoblastic cells, and stimulates IGF-I release from bone organ cultures (110). T3 also stimulates IGF-I protein accumulation in conditioned medium of cultured rat bone tissue (111), IGF-IR mRNA in chondrocytes (112), and IGFBP-4 in osteoblastic cells (113). IGFBP-4 is an inhibitor of cell proliferation, and this may be a mechanism that contributes to the antiproliferative effect of T3 in osteoblasts. T3 also stimulates IGF-I and IGFBP-2 expression in primary rat calvarial osteoblasts, whereas GH has no effect (114).

Current data suggest that the two phases of chondrocyte growth are regulated separately; IGF-I stimulates proliferation, whereas T3 induces hypertrophic differentiation (115). The fact that T4 is also active in this system is noteworthy. T4 is a prohormone that is converted to T3 by 5 '-DI type 1 in peripheral tissues. GH stimulates conversion of T4 to T3 $(116,117)$, suggesting that some effects of GH may involve this pathway. Additionally, GC regulate deiodinase activity in renal tubular cells and the liver whereas T3 regulates $11 \beta \mathrm{HSD} 1$ in liver (118-120). The activity of T4 to promote chondrocyte hypertrophy in serum-free cultures suggests that expression of deiodinase in chondrocytes may be an important determinant of ligand supply to the growth plate that is physiologically significant and could be modulated by GH. Indeed, a recent study has confirmed that growth plate chondrocytes express deiodinase enzymes that may serve to regulate intracellular $\mathrm{T} 3$ concentrations during thyroid hormone-inducible hypertrophic chondrocyte differentiation (121). In view of interactions in other tissues, GC may modulate the supply of T3 in chondrocytes, and vice versa, indicating that local control of intracellular hormone concentrations might be an important mechanism for hormone interactions in the growth plate (Fig. 3).

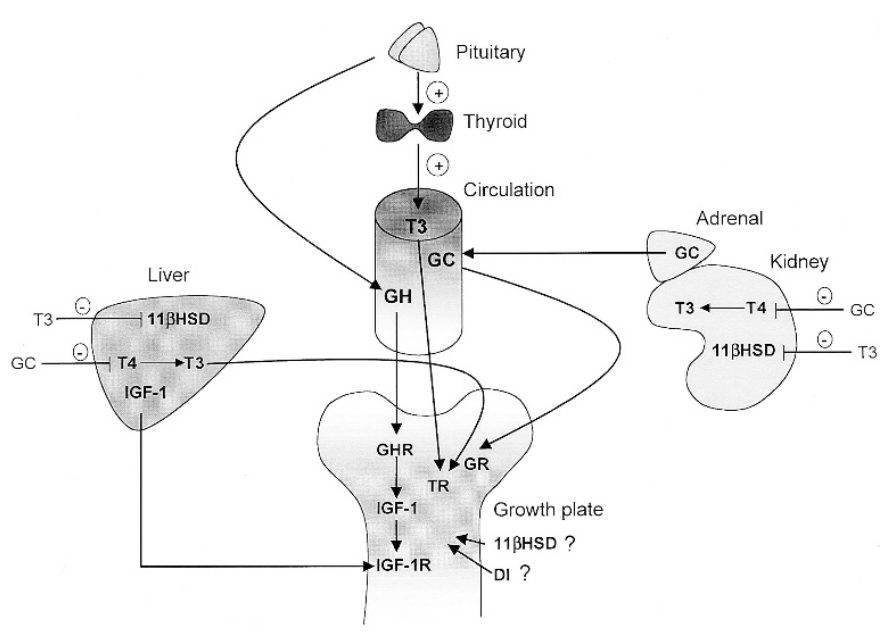

Figure 3. Interaction between GH, IGF-I, T3, and GC. GH stimulates hepatic IGF-I secretion and local production of growth plate IGF-I, and exerts direct actions in the growth plate. Circulating T3 is derived from the thyroid gland and by enzymatic deiodination of T4 in liver and kidney to act on growth plate chondrocytes. GC are secreted by the adrenal glands and circulating concentrations are modulated by activity of the $11 \beta$ HSD enzyme in liver and adipose tissue (type 1 isoform). The regulatory 5'-DI and $11 \beta$ HSD type 2 enzymes may also be expressed in chondrocytes to control local supplies of intracellular T3 and GC. Receptors for each hormone (GHR, IGF-IR, TR, GR) are expressed in growth plate chondrocytes. 
TR- $\alpha 1,-\alpha 2$, and $-\beta 1$ mRNA and $-\alpha 1$ and $-\beta 1$ proteins have been identified in rat growth plate by reverse transcriptase PCR and Western blotting (122). High-affinity nuclear T3 binding sites are present in human fetal epiphyseal chondrocytes (123) and TR- $\alpha 1,-\alpha 2$, and $-\beta 1$ proteins have been identified in chondrocytes at sites of endochondral ossification (124). Until recently, the locations of T3 target cells within the growth plate were unknown. In our studies $(34,125)$, TR- $\alpha 1,-\alpha 2$, and $-\beta 1$ were expressed in reserve and proliferating zone chondrocytes but not in hypertrophic cells. These data suggest that progenitor cells and proliferating chondrocytes are primary T3-target cells but that differentiated chondrocytes lose the ability to express TR and are unresponsive to T3. Primary suspension cultures of rat tibial growth plate chondrocytes express TR- $\alpha 1$, $-\alpha 2$, and $-\beta 1$ mRNA and T3 inhibits clonal expansion and cell proliferation directly while simultaneously promoting hypertrophic chondrocyte differentiation (125). These findings are supported by data that show T3 regulates chondrocyte proliferation and the organization of proliferating chondrocyte columns and is required for terminal hypertrophic differentiation $(112,115,123,126-132)$. This terminal differentiation process is associated with induction of the cyclin-dependent kinase inhibitors p21 and p27 (133), the expression of which was recently shown to be associated with rat epiphyseal chondrocytes induced to terminally differentiate with T3 (134).

We also examined growth plates in thyroid-manipulated rats (34). Hypothyroid growth plates were grossly disorganized and hypertrophic chondrocyte differentiation failed to progress. These effects correlated with absent collagen-X expression and increased PTHrP mRNA expression. In thyrotoxic growth plates, histology was normal but PTHrP receptor mRNA was undetectable. TR- $\alpha 1,-\alpha 2$, and $-\beta 1$ proteins were localized to regions in which PTHrP and PTHrP receptor expression was altered by thyroid status. Thus, dysregulated Ihh/PTHrP feedback loop activity may be a mechanism that underlies growth disorders in childhood thyroid disease, which could result from alteration of the set-point controlling growth plate chondrocyte maturation. Furthermore, the expression of TR in osteoblasts that invade the growth plate (34) also suggests that T3 may integrate the activities of chondrocytes and osteoblasts during ossification.

\section{GENETICALLY MODIFIED MICE}

GHR knockout. GHR null mice exhibit severe postnatal growth retardation, proportionate dwarfism, markedly reduced IGF-I and elevated GH concentrations, and reduced serum-free T3 but normal PTH, testosterone, and estrogen concentrations $(135,136)$. Growth retardation is evident at $2-3 \mathrm{wk}$ of age, is progressive, and its onset is associated with reduced chondrocyte proliferation and growth plate narrowing $(57,136)$. In contrast to the original report in which proportionate dwarfism was identified in $\mathrm{GHR}^{-1-}$ mice (135), others report the presence of disproportionate growth retardation and reduced bone mineral density (136). Treatment with IGF-I almost completely restores growth and bone turnover in $\mathrm{GHR}^{-1-}$ mice, suggesting that most of the effects of GH on growth result from direct actions of IGF-I. It is important to note also that reduced T3 concentrations in $\mathrm{GHR}^{-1-}$ mice may contribute to impaired epiphyseal mineralization (136). Analysis of other mutant mice has further highlighted the physiologic interaction between the $\mathrm{GH}$ axis and thyroid status. The lit/lit mouse has isolated GH deficiency and displays a growth curve that is similar to Laron mice (137). However, the Snell and Ames GH-deficient dwarf mice are more growth retarded than lit/lit mice, probably because they are also hypothyroid $(138,139)$.

IGF-I knockouts. Two IGF-I null mice have been generated $(140,141)$. The mice are growth retarded to $60 \%$ of normal birth weight. Many IGF-I null mice die soon after birth; those surviving to adulthood become further growth retarded, with delayed bone development, and reach only $30 \%$ of normal adult weight. Thus, IGF-I is essential for pre- and postnatal growth and development, although survival of IGF-I null mice to adulthood is dependent on genetic background $(141,142)$, suggesting that unknown genes modify IGF-I action. The IGF-I null growth plate is narrow, with an expanded reserve zone but reduced width of the hypertrophic zone at postnatal $\mathrm{d}$ 20 , the beginning of the GH/IGF-I-dependent growth spurt (143). The expanded reserve zone is considered to be due to increased GH levels. The hypertrophic zone is reduced $35 \%$ in length and individual chondrocyte diameter reduced by $30 \%$, correlating with the degree of growth retardation observed and indicating that IGF-I is required for expansion of hypertrophic chondrocytes. Collagen X, alkaline phosphatase, and bone sialoprotein expression in IGF-I null hypertrophic chondrocytes was normal, suggesting that cells differentiate but do not attain full somatic growth (143). These data support the view that GH expands the pool of chondrocyte progenitors but contradict the hypothesis that IGF-I is responsible for clonal expansion of proliferating cells. The major and unique effect of IGF-I is to amplify hypertrophic chondrocyte size.

To test whether hepatic IGF-I contributes to growth, liverspecific deletion of IGF-I was performed by two groups who crossed the same IGF-I loxP strain with differing Cre recombinase liver-specific strains of mice $(144,145)$. Sjogren et al. (145) used interferon-induced Cre excision of hepatic IGF-I on postnatal d 24, 26, and 28, whereas Yakar et al. (144) used an albumin promoter-driven Cre recombinase to constitutively delete hepatic IGF-I. Circulating IGF-I was reduced by $75 \%$ in both, and hepatic IGF-I expression was abolished, with a marked compensatory increase in circulating GH concentrations. There was no effect on postnatal growth in either study, providing evidence to refute the somatomedin hypothesis (40) and support the view that autocrine/paracrine actions of IGF-I are major determinants of postnatal growth. Nevertheless, such conclusions can be challenged by the argument that circulating concentrations of IGF-I at levels that are $25 \%$ of normal may be sufficient to maintain growth in the presence of elevated circulating GH concentrations.

IGF-IR knockout. IGF-IR deletion is lethal (141, 142, 146). Neonatal mice die of respiratory failure and exhibit severe growth retardation, delayed ossification, and generalized organ hypoplasia (141). Surprisingly, IGF-IR and IGF-IIR double knockout mice are rescued, although postnatal growth is compromised. Triple mutants lacking both IGFR and IGF-II are not viable and growth is retarded to $30 \%$ of normal (146). The IGF-IR mediates signaling by IGF-I and -II, whereas the 
IGF-II receptor regulates IGF-II turnover but does not mediate signal transduction. Thus, the double and triple knockout data are interpreted as indicating that IGF-II, as well as IGF-I, contributes to postnatal growth regulation and signals via an unidentified receptor (146). Subsequent evidence from in vitro and genetic studies indicates that the unidentified receptor may actually be the insulin receptor inasmuch as proliferative and growth-promoting actions of IGF-II may also be mediated, in part, by the insulin receptor $(147,148)$. Thus, in contrast to IGF-I, which acts exclusively via the IGF-IR, IGF-II stimulates both the IGF-IR and the insulin receptor.

GR knockouts. GR gene deletion is lethal and mice die of respiratory failure due to lung atelectasis within a few hours of birth (149). Mice with GR targeted for a point mutation that prevents receptor dimerization and abolishes DNA-bindingdependent transcriptional activation were generated (150) to allow analysis of GR signaling pathways that are independent of DNA-binding and require cross-talk with other transcription factors. Such pathways inhibit transcription via protein-protein interactions between GR and other transcription factors, including activator protein- 1 or nuclear factor $-\kappa \mathrm{B}$, or cause activation of transcription in the case of GR and STAT5 (151). Although the skeletal phenotype of these mice has not been studied, the GC effects on collagenase- 3 and gelatinase B gene expression are now known to be independent of DNA binding (150), suggesting that GC regulation of matrix metalloproteinases is highly complex and involves other signaling pathways.

TR knockouts. The skeletal phenotypes of TR knockout mice (Table 1) (152-156) reinforce the view that T3 acts directly in growth plate cartilage. In TR- $\alpha^{-1-}$ mice there is growth arrest and disorganization of growth plate chondrocytes, with delayed cartilage mineralization and bone formation. These abnormalities result from severe hypothyroidism due to impaired thyroid hormone production at weaning, as the phenotype can be rescued by $\mathrm{T} 4$
(154). This suggests that TR- $\beta$ can compensate for TR- $\alpha$ in the growth plate. Nevertheless, TR- $\beta$ is not essential for bone development inasmuch as TR- $\beta$ null mice $(152,153)$ show no evidence of growth retardation or developmental abnormalities in bone and cartilage. Furthermore, double knockout of both TR- $\alpha$ and $-\beta$ genes fails to modify the skeletal phenotype seen in TR- $\alpha^{-1-}$ null mice (155). The TR- $\alpha^{-1-}$ mutation results in deletion of TR- $\alpha 1$ and $-\alpha 2$ proteins but preservation of two truncated isoforms, TR- $\Delta \alpha 1$ and TR- $\Delta \alpha 2$, that arise from a novel promoter in intron 7 (157). In contrast to TR- $\alpha^{-/-}$mice, TR- $\alpha 1^{-/-}$mice $(156,158)$ do not exhibit skeletal abnormalities and retain expression of TR- $\alpha 2$ and $-\Delta \alpha 2$ but lack TR- $\alpha 1$ and $-\Delta \alpha 1$. Interestingly, TR$\alpha 1^{-/-} \beta^{-/-}$double knockouts experience growth retardation (156) associated with an inhibition of the GH/IGF-I axis. However, GH substitution in these animals reverses the growth phenotype but not the defective ossification (159), suggesting that TR are important both for the regulation of the GH/IGF-I axis and for direct effects on cartilage. Furthermore, these animals suggest a role for TR- $\alpha 2$ in bone development. This argument, however, has been difficult to test by selective deletion of TR- $\alpha 2$ because TR- $\alpha 1$ is markedly overexpressed in TR- $\alpha 2^{-/-}$mice, thereby confusing phenotypic interpretation (160). To investigate this issue further, mice devoid of all known TR- $\alpha$ isoforms were generated (161). These TR- $\alpha^{0 / 0}$ mice exhibit all features of the previously described TR- $\alpha 1^{-/-}$mice (158), but also display retarded growth and delayed bone maturation. The skeletal phenotype of TR $\alpha^{0 / 0}$ mice includes retarded ossification, failed hypertrophic chondrocyte differentiation, and disorganized growth plate architecture. Importantly, TR- $\alpha^{0 / 0}$ mice are euthyroid and pituitary GH synthesis is normal. The data suggest that severe hypothyroidism may be more detrimental to endochondral ossification than deletion of all products of the TR- $\alpha$ gene and support the notion that there is functional redundancy between TR isoforms in the growth plate.

Table 1. Genotypes and growth characteristics of TR null mice

\begin{tabular}{|c|c|c|c|c|c|}
\hline Genotype (reference) & Deleted TR mRNA & $\begin{array}{c}\text { Expressed TR } \\
\text { mRNA }\end{array}$ & Thyroid status & GH status & $\begin{array}{l}\text { Growth } \\
\text { retardation }\end{array}$ \\
\hline $\begin{array}{l}\text { TR- } \alpha \text { mutants } \\
\qquad \alpha 1^{-/-}(158)\end{array}$ & $\alpha 1, \Delta \alpha 1$ & $\begin{array}{l}\alpha 2, \Delta \alpha 2, \text { all } \beta \\
\text { mRNA }\end{array}$ & $\begin{array}{l}\text { Mildly } \\
\text { hypothyroid }\end{array}$ & Normal & - \\
\hline$\alpha 2^{-/-}(160)$ & $\alpha 2, \Delta \alpha 2$ & $\begin{array}{l}\alpha 1, * \Delta \alpha 1 \text {, all } \beta \\
\text { mRNA }\end{array}$ & $\begin{array}{l}\text { Mildly } \\
\text { hypothyroid }\end{array}$ & $\begin{array}{l}\text { GH normal, } \\
\text { IGF-I deficient }\end{array}$ & $\begin{array}{c}+/- \text { late } \\
\text { onset }\end{array}$ \\
\hline$\alpha^{-/-}(154)$ & $\alpha 1, \alpha 2$ & $\begin{array}{c}\Delta \alpha 1, \Delta \alpha 2, \text { all } \\
\beta \text { mRNA }\end{array}$ & $\begin{array}{l}\text { Grossly } \\
\text { hypothyroid }\end{array}$ & Normal & ++ \\
\hline \multicolumn{6}{|l|}{ TR- $\beta$ mutants } \\
\hline$\beta 2^{-/-}(162)$ & $\beta 2$ & $\begin{array}{l}\text { All } \alpha \text { mRNA, } \\
\beta 1, \beta 3, \Delta \beta 3\end{array}$ & RTH & Mildly deficient & - \\
\hline$\beta^{-1-}(152)$ & All $\beta$ mRNA & All $\alpha$ mRNA & RTH & Mildly deficient & - \\
\hline \multicolumn{6}{|l|}{ TR $-\alpha \beta$ double mutants } \\
\hline$\alpha 1^{-/-} \beta^{-/-}(156)$ & $\alpha 1, \Delta \alpha 1$, all $\beta$ mRNA & $\alpha 2, \Delta \alpha 2$ & Severe RTH & $\begin{array}{c}\text { GH \& IGF-I } \\
\text { deficient }\end{array}$ & ++ \\
\hline
\end{tabular}

$\mathrm{RTH}$, resistance to thyroid hormone. GH status was determined by measurement of pituitary mRNA and/or protein or by GH concentration in serum. IGF-I was measured in serum.

* TR- $\alpha 1$ is overexpressed in $\alpha 2^{-/-}$mice, and presumed consequences of gene targeting on expression of $\Delta \alpha 1, \Delta \alpha 2$ mRNA were not tested in the original studies.

$\dagger \mathrm{TR} \alpha^{010}$ mice show mildly increased sensitivity to thyroid hormones following provocative dynamic testing. 


\section{CONCLUSIONS}

We have reviewed the actions of GH, IGF-I, GC, and T3 during linear growth. Interactions between these hormones to regulate various hypothalamopituitary axes have long been understood, but recent interest from a variety of disciplines, including the broad fields of developmental biology, hormone action, and bone and cartilage metabolism, has led to a new appreciation of the epiphyseal growth plate. This organ is a point of convergence for interactions between circulating hormones and locally acting autocrine/paracrine factors that are achieved by mutual regulation of hormone availability and receptor expression in growth plate chondrocytes. We suggest that GH, IGF-I, GC, and T3 signaling pathways are integrated by such complex interactions to regulate, for example, the set point of the Ihh/PTHrP feedback loop to control the pace of growth plate chondrocyte differentiation and linear growth. A clearer understanding of the molecular basis for these interactions in humans will facilitate the design of new, targeted approaches to treat childhood growth retardation.

\section{REFERENCES}

1. Pellegrini-Bouiller I, Belicar P, Barlier A, Gunz G, Charvet JP, Jaquet P, Brue T, Vialettes B, Enjalbert A 1996 A new mutation of the gene encoding the transcription factor Pit-1 is responsible for combined pituitary hormone deficiency. J Clin Endocrinol Metab 81:2790-2796

2. Cogan JD, Phillips III JA, Schenkman SS, Milner RD, Sakati N 1994 Familial growth hormone deficiency: a model of dominant and recessive mutations affecting a monomeric protein. J Clin Endocrinol Metab 79:1261-1265

3. Wu W, Cogan JD, Pfaffle RW, Dasen JS, Frisch H, O'Connell SM, Flynn SE, Brown MR, Mullis PE, Parks JS, Phillips III JA, Rosenfeld MG 1998 Mutations in PROP1 cause familial combined pituitary hormone deficiency. Nat Genet 18:147-149

4. Wajnrajch MP, Gertner JM, Harbison MD, Chua Jr SC, Leibel RL 1996 Nonsense mutation in the human growth hormone-releasing hormone receptor causes growth failure analogous to the little (lit) mouse. Nat Genet 12:88-90

5. Cameron FJ, Khadilkar VV, Stanhope R 1999 Pituitary dysfunction, morbidity and mortality with congenital midline malformation of the cerebrum. Eur J Pediatr 158:97-102

6. Thomsett MJ, Conte FA, Kaplan SL, Grumbach MM 1980 Endocrine and neurologic outcome in childhood craniopharyngioma: review of effect of treatment in 42 patients. J Pediatr 97:728-735

7. Shalet SM, Crowne EC, Didi MA, Ogilvy-Stuart AL, Wallace WH 1992 Irradiationinduced growth failure. Baillieres Clin Endocrinol Metab 6:513-526

8. Blizzard RM, Bulatovic A 1992 Psychosocial short stature: a syndrome with many variables. Baillieres Clin Endocrinol Metab 6:687-712

9. Spiliotis BE, August GP, Hung W, Sonis W, Mendelson W, Bercu BB 1984 Growth hormone neurosecretory dysfunction. A treatable cause of short stature. JAMA 251:2223-2230

10. Rosenfeld RG, Rosenbloom AL, Guevara-Aguirre J 1994 Growth hormone (GH) insensitivity due to primary GH receptor deficiency. Endocr Rev 15:369-390

11. Abdenur JE, Pugliese MT, Cervantes C, Fort P, Lifshitz F 1992 Alterations in spontaneous growth hormone $(\mathrm{GH})$ secretion and the response to GH-releasing hormone in children with nonorganic nutritional dwarfing. J Clin Endocrinol Metab 75:930-934

12. Woods KA, Camacho-Hubner C, Savage MO, Clark AJ 1996 Intrauterine growth retardation and postnatal growth failure associated with deletion of the insulin-like growth factor I gene. N Engl J Med 335:1363-1367

13. Magiakou MA, Mastorakos G, Chrousos GP 1994 Final stature in patients with endogenous Cushing's syndrome. J Clin Endocrinol Metab 79:1082-1085

14. Avioli LV 1993 Glucocorticoid effects on statural growth. Br J Rheumatol 32(suppl 2):27-30

15. LoCascio V, Bonucci E, Imbimbo B, Ballanti P, Adami S, Milani S, Tartarotti D, DellaRocca C 1990 Bone loss in response to long-term glucocorticoid therapy. Bone Miner 8:39-51

16. Barkan AL, DeMott-Friberg R, Samuels MH 2000 Growth hormone (GH) secretion in primary adrenal insufficiency: effects of cortisol withdrawal and patterned replacement on GH pulsatility and circadian rhythmicity. Pituitary 3:175-179

17. Jux C, Leiber K, Hugel U, Blum W, Ohlsson C, Klaus G, Mehls O 1998 Dexamethasone impairs growth hormone (GH)-stimulated growth by suppression of local insulin-like growth factor (IGF)-I production and expression of GH- and IGF-Ireceptor in cultured rat chondrocytes. Endocrinology 139:3296-3305

18. Luengo M, Picado C, Piera C, Guanabens N, Montserrat JM, Rivera J, Setoain J 1991 Intestinal calcium absorption and parathyroid hormone secretion in asthmatic patients on prolonged oral or inhaled steroid treatment. Eur Respir J 4:441-444
19. Reid IR, Ibbertson HK 1987 Evidence for decreased tubular reabsorption of calcium in glucocorticoid-treated asthmatics. Horm Res 27:200-204

20. Montecucco C, Caporali R, Caprotti P, Caprotti M, Notario A 1992 Sex hormones and bone metabolism in postmenopausal rheumatoid arthritis treated with two different glucocorticoids. J Rheumatol 19:1895-1900

21. Soyka LA, Fairfield WP, Klibanski A 2000 Clinical review 117: hormonal determinants and disorders of peak bone mass in children. J Clin Endocrinol Metab $85: 3951-3963$

22. Reiter EO, Rosenfeld RG 1998 Normal and aberrant growth. In: Wilson JD, Foster DW, Kronenberg HM, Larsen PR (eds) Williams Textbook of Endocrinology. WB Saunders, Philadelphia, pp 1427-1507

23. Weiss RE, Refetoff S 1996 Effect of thyroid hormone on growth. Lessons from the syndrome of resistance to thyroid hormone. Endocrinol Metab Clin North Am 25:719-730

24. Rivkees SA, Bode HH, Crawford JD 1988 Long-term growth in juvenile acquired hypothyroidism: the failure to achieve normal adult stature. N Engl J Med 318:599-602

25. Segni M, Leonardi E, Mazzoncini B, Pucarelli I, Pasquino AM 1999 Special features of Graves' disease in early childhood. Thyroid 9:871-877

26. Kember NF 1993 Cell kinetics and the control of bone growth. Acta Paediatr Suppl 82(suppl 391):61-65

27. Hunziker EB 1994 Mechanism of longitudinal bone growth and its regulation by growth plate chondrocytes. Microsc Res Tech 28:505-519

28. Lanske B, Karaplis AC, Lee K, Luz A, Vortkamp A, Pirro A, Karperien M, Defize LHK, Ho C, Mulligan RC, Abou-Samra AB, Juppner H, Segre GV, Kronenberg HM 1996 PTH/PTHrP receptor in early development and Indian hedgehog-regulated bone growth. Science 273:663-666

29. Vortkamp A, Lee K, Lanske B, Segre GV, Kronenberg HM, Tabin CJ 1996 Regulation of rate of cartilage differentiation by Indian hedgehog and PTH-related protein. Science 273:613-622

30. Karaplis AC, Luz A, Glowacki J, Bronson RT, Tybulewicz VL, Kronenberg HM, Mulligan RC 1994 Lethal skeletal dysplasia from targeted disruption of the parathyroid hormone-related peptide gene. Genes Dev 8:277-289

31. Weir EC, Philbrick WM, Amling M, Neff LA, Baron R, Broadus AE 1996 Targeted overexpression of parathyroid hormone-related peptide in chondrocytes causes chondrodysplasia and delayed endochondral bone formation. Proc Natl Acad Sci U S A 93:10240-10245

32. Chung U, Schipani E, McMahon AP, Kronenberg HM 2001 Indian hedgehog couples chondrogenesis to osteogenesis in endochondral bone development. J Clin Invest 107:295-304

33. Yoshida E, Noshiro M, Kawamoto T, Tsutsumi S, Kuruta Y, Kato Y 2001 Direct inhibition of Indian hedgehog expression by parathyroid hormone (PTH)/PTHrelated peptide and up-regulation by retinoic acid in growth plate chondrocyte cultures. Exp Cell Res 265:64-72

34. Stevens DA, Hasserjian RP, Robson H, Siebler T, Shalet SM, Williams GR 2000 Thyroid hormones regulate hypertrophic chondrocyte differentiation and expression of parathyroid hormone-related peptide and its receptor during endochondral bone formation. J Bone Miner Res 15:2431-2442

35. Grimsrud CD, Romano PR, D'Souza M, Puzas JE, Schwarz EM, Reynolds PR, Roiser RN, O'Keefe RJ 2001 BMP signaling stimulates chondrocyte maturation and the expression of Indian hedgehog. J Orthop Res 19:18-25

36. Farquharson C, Jefferies D, Seawright E, Houston B 2001 Regulation of chondrocyte terminal differentiation in the postembryonic growth plate: the role of the PTHrPIndian hedgehog axis. Endocrinology 142:4131-4140

37. Schipani E, Kruse K, Juppner H 1995 A constitutively active mutant PTH-PTHrP receptor in Jansen-type metaphyseal chondrodysplasia. Science 268:98-100

38. Jobert AS, Zhang P, Couvineau A, Bonaventure J, Roume J, Le Merrer M, Silve C 1998 Absence of functional receptors for parathyroid hormone and parathyroid hormone-related peptide in Blomstrand chondrodysplasia. J Clin Invest 102:34-40

39. Le Roith D, Bondy C, Yakar S, Liu JL, Butler A 2001 The somatomedin hypothesis: 2001. Endocr Rev 22:53-74

40. Daughaday WH, Hall K, Raben MS, Salmon Jr WD, van den Brande JL, van Wyk JJ 1972 Somatomedin: proposed designation for sulphation factor. Nature 235:107

41. Green H, Morikawa M, Nixon T 1985 A dual effector theory of growth-hormone action. Differentiation 29:195-198

42. Reinecke M, Schmid AC, Heyberger-Meyer B, Hunziker EB, Zapf J 2000 Effect of growth hormone and insulin-like growth factor I (IGF-I) on the expression of IGF-I messenger ribonucleic acid and peptide in rat tibial growth plate and articular chondrocytes in vivo. Endocrinology 141:2847-2853

43. Ohlsson C, Sjogren K, Jansson JO, Isaksson OG 2000 The relative importance of endocrine versus autocrine/paracrine insulin-like growth factor-I in the regulation of body growth. Pediatr Nephrol 14:541-543

44. Isaksson OG, Jansson JO, Gause IA 1982 Growth hormone stimulates longitudinal bone growth directly. Science 216:1237-1239

45. Schlechter NL, Russell SM, Spencer EM, Nicoll CS 1986 Evidence suggesting that the direct growth-promoting effect of growth hormone on cartilage in vivo is mediated by local production of somatomedin. Proc Natl Acad Sci U S A 83:7932-7934

46. Lindahl A, Isgaard J, Nilsson A, Isaksson OG 1986 Growth hormone potentiates colony formation of epiphyseal chondrocytes in suspension culture. Endocrinology 118:1843-1848

47. Hunziker EB, Wagner J, Zapf J 1994 Differential effects of insulin-like growth factor I and growth hormone on developmental stages of rat growth plate chondrocytes in vivo. J Clin Invest 93:1078-1086

48. Ohlsson C, Bengtsson BA, Isaksson OG, Andreassen TT, Slootweg MC 1998 Growth hormone and bone. Endocr Rev 19:55-79

49. Edmondson SR, Baker NL, Oh J, Kovacs G, Werther GA, Mehls O 2000 Growth hormone receptor abundance in tibial growth plates of uremic rats: GH/IGF-I treatment. Kidney Int 58:62-70 
50. Olney RC, Mougey EB 1999 Expression of the components of the insulin-like growth factor axis across the growth-plate. Mol Cell Endocrinol 156:63-71

51. Barnard R, Haynes KM, Werther GA, Waters MJ 1988 The ontogeny of growth hormone receptors in the rabbit tibia. Endocrinology 122:2562-2569

52. Trippel SB, Van Wyk JJ, Foster MB, Svoboda ME 1983 Characterization of a specific somatomedin-c receptor on isolated bovine growth plate chondrocytes. Endocrinology 112:2128-2136

53. Werther GA, Haynes KM, Barnard R, Waters MJ 1990 Visual demonstration of growth hormone receptors on human growth plate chondrocytes. J Clin Endocrinol Metab 70:1725-1731

54. Wang E, Wang J, Chin E, Zhou J, Bondy CA 1995 Cellular patterns of insulin-like growth factor system gene expression in murine chondrogenesis and osteogenesis. Endocrinology 136:2741-2751

55. Herrington J, Smit LS, Schwartz J, Carter-Su C 2000 The role of STAT proteins in growth hormone signaling. Oncogene 19:2585-2597

56. Teglund S, McKay C, Schuetz E, van Deursen JM, Stravopodis D, Wang D, Brown M, Bodner S, Grosveld G, Ihle JN 1998 Stat5a and Stat5b proteins have essential and nonessential, or redundant, roles in cytokine responses. Cell 93:841-850

57. Sims NA, Clement-Lacroix P, Da Ponte F, Bouali Y, Binart N, Moriggl R, Goffin V, Coschigano K, Gaillard-Kelly M, Kopchick J, Baron R, Kelly PA 2000 Bone homeostasis in growth hormone receptor-null mice is restored by IGF-I but independent of stat5. J Clin Invest 106:1095-1103

58. Burke D, Wilkes D, Blundell TL, Malcolm S 1998 Fibroblast growth factor receptors: lessons from the genes. Trends Biochem Sci 23:59-62

59. De Luca F, Baron J 1999 Control of bone growth by fibroblast growth factors. Trends Endocrinol Metab 10:61-65

60. Wilkie AO, Morriss-Kay GM 2001 Genetics of craniofacial development and malformation. Nat Rev Genet 2:458-468

61. Sahni M, Raz R, Coffin JD, Levy D, Basilico C 2001 STAT1 mediates the increased apoptosis and reduced chondrocyte proliferation in mice overexpressing FGF2. Development 128:2119-2129

62. Sahni M, Ambrosetti DC, Mansukhani A, Gertner R, Levy D, Basilico C 1999 FGF signaling inhibits chondrocyte proliferation and regulates bone development through the STAT-1 pathway. Genes Dev 13:1361-1366

63. Lazowski DA, Fraher LJ, Hodsman A, Steer B, Modrowski D, Han VK 1994 Regional variation of insulin-like growth factor-I gene expression in mature rat bone and cartilage. Bone 15:563-576

64. De Los Rios P, Hill DJ 2000 Expression and release of insulin-like growth factor binding proteins in isolated epiphyseal growth plate chondrocytes from the ovine fetus. J Cell Physiol 183:172-181

65. Kiepe D, Andress DL, Mohan S, Standker L, Ulinski T, Himmele R, Mehls O, Tonshoff B 2001 Intact IGF-binding protein-4 and -5 and their respective fragments isolated from chronic renal failure serum differentially modulate IGF-I actions in cultured growth plate chondrocytes. J Am Soc Nephrol 12:2400-2410

66. Spagnoli A, Hwa V, Horton WA, Lunstrum GP, Roberts Jr CT, Chiarelli F, Torello M, Rosenfeld RG 2001 Antiproliferative effects of insulin-like growth factorbinding protein-3 in mesenchymal chondrogenic cell line RCJ3.1C5.18. relationship to differentiation stage. J Biol Chem 276:5533-5540

67. Cox GN, McDermott MJ, Merkel E, Stroh CA, Ko SC, Squires CH, Gleason TM, Russell D 1994 Recombinant human insulin-like growth factor (IGF)-binding protein-1 inhibits somatic growth stimulated by IGF-I and growth hormone in hypophysectomized rats. Endocrinology 135:1913-1920

68. Koedam JA, Hoogerbrugge CM, Van Buul-Offers SC 2000 Differential regulation of IGF-binding proteins in rabbit costal chondrocytes by IGF-I and dexamethasone. $\mathrm{J}$ Endocrinol 165:557-567

69. Jones JI, Gockerman A, Busby Jr WH, Camacho-Hubner C, Clemmons DR 1993 Extracellular matrix contains insulin-like growth factor binding protein-5: potentiation of the effects of IGF-I. J Cell Biol 121:679-687

70. Andress DL, Birnbaum RS 1992 Human osteoblast-derived insulin-like growth factor (IGF) binding protein-5 stimulates osteoblast mitogenesis and potentiates IGF action. J Biol Chem 267:22467-22472

71. Rajaram S, Baylink DJ, Mohan S 1997 Insulin-like growth factor-binding proteins in serum and other biological fluids: regulation and functions. Endocr Rev 18:801-831

72. Conover CA, Powell DR 1991 Insulin-like growth factor (IGF)-binding protein-3 blocks IGF-I-induced receptor down-regulation and cell desensitization in cultured bovine fibroblasts. Endocrinology 129:710-716

73. Plotnikov AN, Hubbard SR, Schlessinger J, Mohammadi M 2000 Crystal structures of two FGF-FGFR complexes reveal the determinants of ligand-receptor specificity. Cell 101:413-424

74. Schlessinger J, Plotnikov AN, Ibrahimi OA, Eliseenkova AV, Yeh BK, Yayon A, Linhardt RJ, Mohammadi M 2000 Crystal structure of a ternary FGF-FGFR-heparin complex reveals a dual role for heparin in FGFR binding and dimerization. Mol Cell 6:743-750

75. Ornitz DM 2000 FGFs, heparan sulfate and FGFRs: complex interactions essential for development. Bioessays 22:108-112

76. Guimond SE, Turnbull JE 1999 Fibroblast growth factor receptor signalling is dictated by specific heparan sulphate saccharides. Curr Biol 9:1343-1346

77. Weiss A, Raz E, Silbermann M 1986 Effects of systemic glucocorticoids on the degradation of glycosaminoglycans in the mandibular condylar cartilage of newborn mice. Bone Miner 1:335-346

78. Hill DJ 1981 Effects of cortisol on cell proliferation and proteoglycan synthesis and degradation in cartilage zones of the calf costochondral growth plate in vitro with and without rat plasma somatomedin activity. J Endocrinol 88:425-435

79. Baron J, Huang Z, Oerter KE, Bacher JD, Cutler GB 1992 Dexamethasone acts locally to inhibit longitudinal bone growth in rabbits. Am J Physiol 263:E489-E492
80. Silvestrini G, Mocetti P, Ballanti P, Di Grezia R, Bonucci E 1999 Cytochemical demonstration of the glucocorticoid receptor in skeletal cells of the rat. Endocr Res 25:117-128

81. Abu EO, Horner A, Kusec V, Triffitt JT, Compston JE 2000 The localization of the functional glucocorticoid receptor alpha in human bone. J Clin Endocrinol Metab 85:883-889

82. Canalis E 1996 Clinical review 83: Mechanisms of glucocorticoid action in bone: implications to glucocorticoid-induced osteoporosis. J Clin Endocrinol Metab 81:3441-3447

83. Canalis E 1998 Inhibitory actions of glucocorticoids on skeletal growth. Is local insulin-like growth factor I to blame? Endocrinology 139:3041-3042

84. Eberhardt AW, Yeager-Jones A, Blair HC 2001 Regional trabecular bone matrix degeneration and osteocyte death in femora of glucocorticoid-treated rabbits. Endocrinology 142:1333-1340

85. Silvestrini G, Ballanti P, Patacchioli FR, Mocetti P, Di Grezia R, Wedard BM, Angelucci L, Bonucci E 2000 Evaluation of apoptosis and the glucocorticoid receptor in the cartilage growth plate and metaphyseal bone cells of rats after high-dose treatment with corticosterone. Bone 26:33-42

86. Mocetti P, Silvestrini G, Ballanti P, Patacchioli FR, Di Grezia R, Angelucci L, Bonucci E $2001 \mathrm{Bcl}-2$ and Bax expression in cartilage and bone cells after high-dose corticosterone treatment in rats. Tissue Cell 33:1-7

87. Annefeld M 1992 Changes in rat epiphyseal cartilage after treatment with dexamethasone and glycosaminoglycan-peptide complex. Pathol Res Pract 188:649-652

88. Grigoriadis AE, Heersche JN, Aubin JE 1996 Analysis of chondroprogenitor frequency and cartilage differentiation in a novel family of clonal chondrogenic rat cell lines. Differentiation 60:299-307

89. Grigoriadis AE, Heersche JN, Aubin JE 1988 Differentiation of muscle, fat, cartilage, and bone from progenitor cells present in a bone-derived clonal cell population: effect of dexamethasone. J Cell Biol 106:2139-2151

90. Sekiya I, Koopman P, Tsuji K, Mertin S, Harley V, Yamada Y, Shinomiya K, Nifuji A, Noda M 2001 Dexamethasone enhances SOX9 expression in chondrocytes. J Endocrinol 169:573-579

91. Murakami S, Kan M, McKeehan WL, de Crombrugghe B 2000 Up-regulation of the chondrogenic Sox9 gene by fibroblast growth factors is mediated by the mitogenactivated protein kinase pathway. Proc Natl Acad Sci U S A 97:1113-1118

92. de Crombrugghe B, Lefebvre V, Behringer RR, Bi W, Murakami S, Huang W 2000 Transcriptional mechanisms of chondrocyte differentiation. Matrix Biol 19:389-394

93. Huang W, Chung U, Kronenberg HM, de Crombrugghe B 2001 The chondrogenic transcription factor Sox9 is a target of signaling by the parathyroid hormone-related peptide in the growth plate of endochondral bones. Proc Natl Acad Sci U S A 98:160-165

94. Baron J, Klein KO, Colli MJ, Yanovski JA, Novosad JA, Bacher JD, Cutler Jr GB 1994 Catch-up growth after glucocorticoid excess: a mechanism intrinsic to the growth plate. Endocrinology 135:1367-1371

95. Gafni RI, Baron J 2000 Catch-up growth: possible mechanisms. Pediatr Nephrol $14: 616-619$

96. Allen DB 1996 Growth suppression by glucocorticoid therapy. Endocrinol Metab Clin North Am 25:699-717

97. Luo JM, Murphy LJ 1989 Dexamethasone inhibits growth hormone induction of insulin-like growth factor-I (IGF-I) messenger ribonucleic acid (mRNA) in hypophysectomized rats and reduces IGF-I mRNA abundance in the intact rat. Endocrinology 125:165-171

98. Itagane Y, Inada H, Fujita K, Isshiki G 1991 Interactions between steroid hormones and insulin-like growth factor-I in rabbit chondrocytes. Endocrinology 128:1419-1424

99. Klaus G, Jux C, Fernandez P, Rodriguez J, Himmele R, Mehls O 2000 Suppression of growth plate chondrocyte proliferation by corticosteroids. Pediatr Nephrol $14: 612-615$

100. Rooman R, Koster G, Bloemen R, Gresnigt R, van Buul-Offers SC 1999 The effect of dexamethasone on body and organ growth of normal and IGF-II-transgenic mice. J Endocrinol 163:543-552

101. Heinrichs C, Yanovski JA, Roth AH, Yu YM, Domene HM, Yano K, Cutler GB, Baron J 1994 Dexamethasone increases growth hormone receptor messenger ribonucleic acid levels in liver and growth plate. Endocrinology 135:1113-1118

102. Swolin-Eide D, Nilsson A, Ohlsson C 1998 Cortisol increases growth hormonereceptor expression in human osteoblast-like cells. J Endocrinol 156:99-105

103. Moore JS, Monson JP, Kaltsas G, Putignano P, Wood PJ, Sheppard MC, Besser GM, Taylor NF, Stewart PM 1999 Modulation of 11beta-hydroxysteroid dehydrogenase isozymes by growth hormone and insulin-like growth factor: in vivo and in vitro studies. J Clin Endocrinol Metab 84:4172-4177

104. Stewart PM, Krozowski ZS 199911 beta-Hydroxysteroid dehydrogenase. Vitam Horm 57:249-324

105. Cooper MS, Walker EA, Bland R, Fraser WD, Hewison M, Stewart PM 2000 Expression and functional consequences of 11 beta-hydroxysteroid dehydrogenase activity in human bone. Bone 27:375-381

106. Bland R, Worker CA, Noble BS, Eyre LJ, Bujalska IJ, Sheppard MC, Stewart PM, Hewison M 1999 Characterization of 11 beta-hydroxysteroid dehydrogenase activity and corticosteroid receptor expression in human osteosarcoma cell lines. J Endocrinol 161:455-464

107. Woitge H, Harrison J, Ivkosic A, Krozowski Z, Kream B 2001 Cloning and in Vitro Characterization of alpha1(I)-collagen 11 beta-hydroxysteroid dehydrogenase type 2 transgenes as models for osteoblast-selective inactivation of natural glucocorticoids. Endocrinology 142:1341-1348

108. Lewinson D, Harel Z, Shenzer P, Silbermann M, Hochberg Z 1989 Effect of thyroid hormone and growth hormone on recovery from hypothyroidism of epiphyseal growth plate cartilage and its adjacent bone. Endocrinology 124:937-945 
109. Lewinson D, Bialik GM, Hochberg Z 1994 Differential effects of hypothyroidism on the cartilage and the osteogenic process in the mandibular condyle: recovery by growth hormone and thyroxine. Endocrinology 135:1504-1510

110. Varga F, Rumpler M, Klaushofer K 1994 Thyroid hormones increase insulin-like growth factor mRNA levels in the clonal osteoblastic cell line MC3T3-E1. FEBS Lett 345:67-70

111. Lakatos P, Caplice MD, Khanna V, Stern PH 1993 Thyroid hormones increase insulin-like growth factor I content in the medium of rat bone tissue. J Bone Miner Res 8:1475-1481

112. Ohlsson C, Nilsson A, Isaksson O, Bentham J, Lindahl A 1992 Effects of triiodothyronine and insulin-like growth factor-I (IGF-I) on alkaline phosphatase activity, $[3 \mathrm{H}]$ thymidine incorporation and IGF-I receptor mRNA in cultured rat epiphyseal chondrocytes. J Endocrinol 135:115-123

113. Glantschnig H, Varga F, Klaushofer K 1996 Thyroid hormone and retinoic acid induce the synthesis of insulin-like growth factor-binding protein- 4 in mouse osteoblastic cells. Endocrinology 137:281-286

114. Schmid C, Schlapfer I, Futo E, Waldvogel M, Schwander J, Zapf J, Froesch ER 1992 Triiodothyronine (T3) stimulates insulin-like growth factor (IGF)-1 and IGF binding protein (IGFBP)-2 production by rat osteoblasts in vitro. Acta Endocrinol (Copenh) $126: 467-473$

115. Bohme K, Conscience-Egli M, Tschan T, Winterhalter KH, Bruckner P 1992 Induction of proliferation or hypertrophy of chondrocytes in serum-free culture: the role of insulin-like growth factor-I, insulin, or thyroxine. J Cell Biol 116:1035-1042

116. Sato T, Suzukui Y, Taketani T, Ishiguro K, Masuyama T 1977 Enhanced peripheral conversion of thyroxine to triiodothyronine during hGH therapy in $\mathrm{GH}$ deficient children. J Clin Endocrinol Metab 45:324-329

117. Wolthers T, Groftne T, Moller N, Christiansen JS, Orskov H, Weeke J, Jorgensen JO 1996 Calorigenic effects of growth hormone: the role of thyroid hormones. J Clin Endocrinol Metab 81:1416-1419

118. Heyma P, Larkins RG 1982 Glucocorticoids decrease in conversion of thyroxine into 3, 5, 3'-tri-iodothyronine by isolated rat renal tubules. Clin Sci (Colch) 62:215-220

119. Whorwood CB, Sheppard MC, Stewart PM 1993 Tissue specific effects of thyroid hormone on 11 beta-hydroxysteroid dehydrogenase gene expression. J Steroid Biochem Mol Biol 46:539-547

120. Cavalieri RR, Castle JN, McMahon FA 1984 Effects of dexamethasone on kinetics and distribution of triiodothyronine in the rat. Endocrinology 114:215-221

121. Miura M, Tanaka K, Komatsu Y, Suda M, Yasoda A, Sakuma Y, Ozasa A, Nakao K 2002 Thyroid hormones promote chondrocyte differentiation in mouse ATDC5 cells and stimulate endochondral ossification in fetal mouse tibias through iodothyronine deiodinases in the growth plate. J Bone Miner Res 17:443-454

122. Ballock R, Mita BC, Zhou X, Chen DH, Mink LM 1999 Expression of thyroid hormone receptor isoforms in rat growth plate cartilage in vivo. J Bone Miner Res $14: 1550-1556$

123. Carrascosa A, Ferrandez MA, Audi L, Ballabriga A 1992 Effects of triiodothyronine (T3) and identification of specific nuclear T3-binding sites in cultured human fetal epiphyseal chondrocytes. J Clin Endocrinol Metab 75:140-144

124. Abu EO, Bord S, Horner A, Chatterjee VK, Compston JE 1997 The expression of thyroid hormone receptors in human bone. Bone 21:137-142

125. Robson H, Siebler T, Stevens DA, Shalet SM, Williams GR 2000 Thyroid hormone acts directly on growth plate chondrocytes to promote hypertrophic differentiation and inhibit clonal expansion and cell proliferation. Endocrinology 141:3887-3897

126. Ballock RT, Reddi AH 1994 Thyroxine is the serum factor that regulates morphogenesis of columnar cartilage from isolated chondrocytes in chemically defined medium. J Cell Biol 126:1311-1318

127. Quarto R, Campanile G, Cancedda R, Dozin B 1992 Thyroid hormone, insulin, and glucocorticoids are sufficient to support chondrocyte differentiation to hypertrophy: a serum-free analysis. J Cell Biol 119:989-995

128. Ishikawa Y, Genge BR, Wuthier RE, Wu LN 1998 Thyroid hormone inhibits growth and stimulates terminal differentiation of epiphyseal growth plate chondrocytes. J Bone Miner Res 13:1398-1411

129. Burch WM, Lebovitz HE 1982 Triiodothyronine stimulates maturation of porcine growth-plate cartilage in vitro. J Clin Invest 70:496-504

130. Alini M, Kofsky Y, Wu W, Pidoux I, Poole AR 1996 In serum-free culture thyroid hormones can induce full expression of chondrocyte hypertrophy leading to matrix calcification. J Bone Miner Res 11:105-113

131. Burch WM, Van Wyk JJ 1987 Triiodothyronine stimulates cartilage growth and maturation by different mechanisms. Am J Physiol 252:E176-E182

132. Rosenthal AK, Henry LA 1999 Thyroid hormones induce features of the hypertrophic phenotype and stimulate correlates of CPPD crystal formation in articular chondrocytes. J Rheumatol 26:395-401

133. Beier F, Leask TA, Haque S, Chow C, Taylor AC, Lee RJ, Pestell RG, Ballock RT, LuValle P 1999 Cell cycle genes in chondrocyte proliferation and differentiation. Matrix Biol 18:109-120

134. Ballock RT, Zhou X, Mink LM, Chen DH, Mita BC, Stewart MC 2000 Expression of cyclin-dependent kinase inhibitors in epiphyseal chondrocytes induced to terminally differentiate with thyroid hormone. Endocrinology 141:4552-4557

135. Zhou Y, Xu BC, Maheshwari HG, He L, Reed M, Lozykowski M, Okada S, Cataldo L, Coschigamo K, Wagner TE, Baumann G, Kopchick JJ 1997 A mammalian model for Laron syndrome produced by targeted disruption of the mouse growth hormone receptor/binding protein gene (the Laron mouse). Proc Natl Acad Sci U S A 94:13215-13220

136. Sjogren K, Bohlooly YM, Olsson B, Coschigano K, Tornell J, Mohan S, Isaksson OG, Baumann G, Kopchick J, Ohlsson C 2000 Disproportional skeletal growth and markedly decreased bone mineral content in growth hormone receptor $-/-$ mice. Biochem Biophys Res Commun 267:603-608
137. Donahue LR, Beamer WG 1993 Growth hormone deficiency in 'little' mice results in aberrant body composition, reduced insulin-like growth factor-I and insulin-like growth factor-binding protein-3 (IGFBP-3), but does not affect IGFBP-2, -1 or -4. J Endocrinol 136:91-104

138. van Buul S, Van den Brande J 1978 The Snell-dwarfmouse. I. General growth pattern, before and during growth hormone and thyroxine therapy. Acta Endocrinol (Copenh) 89:632-645

139. Bartke A 1965 The response of two types of dwarf mice to growth hormone, thyrotropin, and thyroxine. Gen Comp Endocrinol 5:418-426

140. Powell-Braxton L, Hollingshead P, Warburton C, Dowd M, Pitts-Meek S, Dalton D, Gillett N, Stewart TA 1993 IGF-I is required for normal embryonic growth in mice. Genes Dev 7:2609-2617

141. Liu JP, Baker J, Perkins AS, Robertson EJ, Efstratiadis A 1993 Mice carrying null mutations of the genes encoding insulin-like growth factor I (IGF-1) and type 1 IGF receptor (IGF1R). Cell 75:59-72

142. Baker J, Liu JP, Robertson EJ, Efstratiadis A 1993 Role of insulin-like growth factors in embryonic and postnatal growth. Cell 75:73-82

143. Wang J, Zhou J, Bondy CA 1999 IGF1 promotes longitudinal bone growth by insulin-like actions augmenting chondrocyte hypertrophy. FASEB J 13:1985-1990

144. Yakar S, Liu JL, Stannard B, Butler A, Accili D, Sauer B, LeRoith D 1999 Normal growth and development in the absence of hepatic insulin-like growth factor I. Proc Natl Acad Sci U S A 96:7324-7329

145. Sjogren K, Liu JL, Blad K, Skrtic S, Vidal O, Wallenius V, LeRoith D, Tornell J, Isaksson OG, Jansson JO, Ohlsson C 1999 Liver-derived insulin-like growth factor I (IGF-I) is the principal source of IGF-I in blood but is not required for postnatal body growth in mice. Proc Natl Acad Sci U S A 96:7088-7092

146. Ludwig T, Eggenschwiler J, Fisher P, D’Ercole AJ, Davenport ML, Efstratiadis A 1996 Mouse mutants lacking the type 2 IGF receptor (IGF2R) are rescued from perinatal lethality in IGF2 and IGF1R null backgrounds. Dev Biol 177:517-535

147. Louvi A, Accili D, Efstratiadis A 1997 Growth-promoting interaction of IGF-II with the insulin receptor during mouse embryonic development. Dev Biol 189:33-48

148. Morrione A, Valentinis B, Xu SQ, Yumet G, Louvi A, Efstratiadis A, Baserga R 1997 Insulin-like growth factor II stimulates cell proliferation through the insulin receptor. Proc Natl Acad Sci U S A 94:3777-3782

149. Cole TJ, Blendy JA, Monaghan AP, Krieglstein K, Schmid W, Aguzzi A, Fantuzzi G, Hummler E, Unsicker K, Schutz G 1995 Targeted disruption of the glucocorticoid receptor gene blocks adrenergic chromaffin cell development and severely retards lung maturation. Genes Dev 9:1608-1621

150. Reichardt HM, Kaestner KH, Tuckermann J, Kretz O, Wessely O, Bock R, Gass P, Schmid W, Herrlich P, Angel P, Schutz G 1998 DNA binding of the glucocorticoid receptor is not essential for survival. Cell 93:531-541

151. Reichardt HM, Schutz G 1998 Glucocorticoid signalling-multiple variations of a common theme. Mol Cell Endocrinol 146:1-6

152. Forrest D, Hanebuth E, Smeyne RJ, Everds N, Stewart CL, Wehner JM, Curran T 1996 Recessive resistance to thyroid hormone in mice lacking thyroid hormone receptor beta: evidence for tissue-specific modulation of receptor function. EMBO J 15:3006-3015

153. Forrest D, Erway LC, Ng L, Altschuler R, Curran T 1996 Thyroid hormone receptor beta is essential for development of auditory function. Nat Genet 13:354-357

154. Fraichard A, Chassande O, Plateroti M, Roux JP, Trouillas J, Dehay C, Legrand C, Gauthier K, Kedinger M, Malaval L, Rousset B, Samarut J 1997 The T3R alpha gene encoding a thyroid hormone receptor is essential for post-natal development and thyroid hormone production. EMBO J 16:4412-4420

155. Gauthier K, Chassande O, Plateroti M, Roux JP, Legrand C, Pain B, Rousset B, Weiss R, Trouillas J, Samarut J 1999 Different functions for the thyroid hormone receptors TRalpha and TRbeta in the control of thyroid hormone production and post-natal development. EMBO J 18:623-631

156. Gothe S, Wang Z, Ng L, Kindblom JM, Barros AC, Ohlsson C, Vennstrom B, Forrest D 1999 Mice devoid of all known thyroid hormone receptors are viable but exhibit disorders of the pituitary-thyroid axis, growth, and bone maturation. Genes Dev 13:1329-1341

157. Chassande O, Fraichard A, Gauthier K, Flamant F, Legrand C, Savatier P, Laudet V, Samarut J 1997 Identification of transcripts initiated from an internal promoter in the c-erbA alpha locus that encode inhibitors of retinoic acid receptor-alpha and triiodothyronine receptor activities. Mol Endocrinol 11:1278-1290

158. Wikstrom L, Johansson C, Salto C, Barlow C, Campos Barros A, Baas F, Forrest D, Thoren P, Vennstrom B 1998 Abnormal heart rate and body temperature in mice lacking thyroid hormone receptor alpha 1. EMBO J 17:455-461

159. Kindblom JM, Gothe S, Forrest D, Tornell J, Vennstrom B, Ohlsson C $2001 \mathrm{GH}$ substitution reverses the growth phenotype but not the defective ossification in thyroid hormone receptor alpha 1-/-beta-/- mice. J Endocrinol 171:15-22

160. Salto C, Kindblom JM, Johansson C, Wang Z, Gullberg H, Nordstrom K, Mansen A, Ohlsson C, Thoren P, Forrest D, Vennstrom B 2001 Ablation of TRalpha2 and a concomitant overexpression of alphal yields a mixed hypo- and hyperthyroid phenotype in mice. Mol Endocrinol 15:2115-2128

161. Gauthier K, Plateroti M, Harvey CB, Williams GR, Weiss RE, Refetoff S, Willott JF, Sundin V, Roux J-P, Malaval L, Hara M, Samarut J, Chassande O 2001 Genetic analysis reveals different functions for the products of the TR $\alpha$ locus. Mol Cell Biol 21:4748-4760

162. Abel ED, Boers ME, Pazos-Moura C, Moura E, Kaulbach H, Zakaria M, Lowell B, Radovick S, Liberman MC, Wondisford F 1999 Divergent roles for thyroid hormone receptor beta isoforms in the endocrine axis and auditory system. J Clin Invest 104:291-300 